Психология. Журнал Высшей школы экономики,

2021. T. 18. № 1. C. 71-91. DOI: 10.17323/1813-8918-2021-1-71-91

\title{
РАЗРАБОТКА И АДАПТАЦИЯ МЕТОДИКИ «ИНТЕГРАТИВНЫЙ ОПРОСНИК МЕЖКУЛЬТУРНОЙ КОМПЕТЕНТНОСТИ»
}

\author{
О.Е. ХУХЛАЕВ ${ }^{\mathrm{a}}$ В.В. ГРИЦЕНКО ${ }^{\mathrm{a}}$, А.В. МАКАРЧУК \\ Н.В. ТКАЧЕНКО ${ }^{\mathrm{a}}$, Ш.А. УСУБЯН ${ }^{\mathrm{a}}$, В.А. ШОРОХОВА
}

${ }^{a}$ Московский государственный психолого-педагогический университет, 127051, Россия, Москва,
ул. Сретенка, д. 29
${ }^{b}$ Федеральньй научно-методический центр в области психологии и педагогики толерантности,
127055, Москва, ул. Образщова, д. 11

Резюме

В статье приводятся описание разработки и результаты апробации новой методики «Интегративный опросник межкультурной компетентности», направленной на изучение способности эффективно функционировать при общении с представителями различных культур и в разных культурных средах. Опросник создан на основе интеграции 52 конструктов из 14 методов измерения межкультурной компетентности. Исследование $(\mathrm{N}=$ 1024) показало, что методика содержит четыре субшкалы: «Межкультурная стабильность» (индивидуальные особенности личности, которые позволяют человеку быть устойчивым к стрессовым ситуациям межкультурного общения), «Межкультурный интерес» (желание общаться с людьми из других культур, интерес к культуре и культурным различиям), «Отсутствие этноцентризма» (установка на уважение и принятие культурного разнообразия) и «Управление межкультурным взаимодействием» (владение широким спектром коммуникативных навыков, важных при межкультурном общении). Субшкалы обладают хорошей внутренней согласованностью, а также инвариантностью с некоторыми ограничениями в части сравнения людей разных возрастов. Исследование также продемонстрировало внешнюю валидность методики. Шкалы «Интегративного опросника межкультурной компетентности» положительно связаны с «Расширенной шкалой культурного интеллекта». Люди, демонстрирующие более высокие показатели по отдельным шкалам опросника, отличаются бо́льшим количеством конкретных межкультурных достижений. Наблюдаются предсказуемые взаимосвязи опросника с показателями адаптации иностранных студентов, выраженностью эмоционального выгорания и самоэффективности у педагогов, работающих в мультикультурной среде.

Ключевые слова: межкультурная компетентность, межкультурная коммуникация, культурный интеллект.

Исследование выполнено при поддержке РФФИ, проект № 19-013-00892 «Интегративная социально-психологическая модель оценки и прогнозирования эффективности межкультурного взаимодействия».

Авторы благодарят доктора психологических наук, зав. кафедрой психологии КЧГУ имени У.Д. Алиева Ф.О. Семенову и студентов КЧГУ имени У.Д. Алиева за содействие в проведении исследования. 


\section{Введение}

Межкультурная компетентность в наиболее широком контексте рассматривается как способность человека эффективно функционировать при общении с представителями различных культур и в разных культурных средах (Whaley, Davis, 2007). Ее важность для решения конкретных профессиональных задач в мультикультурной среде очевидна. Причем если достижение определенного уровня межкультурной компетентности позволяет решать проблемы, связанные с культурными различиями, то высокий уровень межкультурных способностей позволяет использовать культурное разнообразие и как ресурс (Хухлаев, Чибисова, 2010). В этой связи вопрос измерения межкультурной компетентности является крайне актуальным как для исследовательского поля, так и для психологической практики.

Теоретическое понимание межкультурной компетентности крайне разнообразно и многообразно: существует более 30 моделей межкультурной компетентности и более чем 300 конструктов, которые являются ее составляющими (Leung et al., 2014). Инструментов измерения межкультурной компетентности также достаточно много. Разные авторы обозначают различное количество методик с доказанной внешней и внутренней валидностью (Matsumoto, Hwang, 2013; Leung et al., 2014). Из них на российской выборке адаптирована лишь одна - «Расширенная шкала культурного интеллекта» (Солдатова и др., 2018). Данная методика базируется на крайне актуальном, но весьма своеобразном теоретическом подходе к пониманию межкультурной компетентности - теории культурного интеллекта как одного из видов социального интеллекта (Earley, Ang, 2003), нацеленного на решение задач, связанных с кросс-культурным взаимодействием. Существуют и другие, концептуально отличающиеся подходы к теоретическому пониманию межкультурной компетентности, воплощенные в конкретные инструменты ее измерения (например, модель кросскультурного психологического капитала - Dollwet, Reichard, 2014).

При этом значительная часть зарубежных инструментов измерения межкультурной компетентности предназначена для коммерческого использования, охраняется авторским правом, в связи с чем существенно затруднено решение вопроса их перевода и адаптации.

Следует подчеркнуть, что ряд инструментов, позиционирующихся как нацеленные на измерение межкультурной компетентности, по факту изучают более широкие личностные особенности. Так, многие вопросы из широкоизвестного «Опросника мультикультурной личности» (MPQ) (Van der Zee, Van Oudenhoven, 2000, 2001) сформулированы без учета специфики межкультурного общения (например, «Я имею устоявшиеся привычки»).

Мы считаем, что индивидуальные особенности, не являющиеся специфичными для межкультурной коммуникации, следует измерять соответствующими универсальными инструментами, прошедшими широкую апробацию. Такой подход позволяет избежать спутанности между разными видами компетентности, а также личностными особенностями, способствующими тому или иному виду деятельности. 
В силу всех причин, указанных выше, существует потребность в методике измерения межкультурной компетентности: а) адаптированной к российскому контексту, б) созданной на основе интеграции широкого круга подходов к пониманию данного феномена и в) нацеленной на измерение именно межкультурной компетентности, а не более широких феноменов. В данной статье изложено теоретическое обоснование, описан процесс создания и приведены результаты исследования внутренней и внешней валидности русскоязычного «Интегративного опросника межкультурной компетентности», созданного на основе комплексного анализа ряда подходов к пониманию процесса достижения эффективности в межкультурном общении.

Основываясь на подходе К. Леунга (Leung) и его коллег (Leung et al., 2014), мы выбрали рамочную структуру межкультурной компетентности из трех составляющих.

Межкультурные черть - наиболее устойчивые индивидуально-личностные образования, определяющие те или иные паттерны поведения человека в условиях межкультурного взаимодействия и тем самым способствующие или препятствующие успешности межкультурной адаптации. Межкультурные установки - особенности мировоззрения, связанные с межкультурным общением и обеспечивающие его мотивацию, которая, в свою очередь, приводит к эффективности межкультурного взаимодействия. Межкультурные умения и навыки индивида непосредственно обеспечивают его эффективность в конкретных межкультурных взаимодействиях.

Для интегративного анализа мы выбрали 14 моделей межкультурной компетентности, получившие эмпирическое подтверждение и часто используемые в зарубежных исследованиях. Их подробный анализ опубликован отдельно (Гриценко и др., 2020). Мы выделили все конструкты, которые авторы данных моделей включили в свои подходы, и провели их содержательное сопоставление. После удаления полностью дублирующих конструктов мы разделили оставшиеся по трем составляющим межкультурной компетентности: «Межкультурные черты» (20 конструктов), «Межкультурные установки» (11 конструктов) и «Межкультурные умения и навыки» (21 конструкт). При отнесении мы ориентировались на название конструкта и его содержание, как описанное автором, так и отраженное в вопросах, предназначенных для его изучения. Далее, внутри каждой из составляющих межкультурной компетентности мы объединили и дали одно название схожим и/или взаимодополняющим конструктам. Так, к примеру, фактор «Межкультурное общение» из Опросника межкультурной готовности (The Intercultural Readiness Chec; Van der Zee, Brinkmann, 2004) был объединен со схожей шкалой «Коммуникативные навыки» мультикомпонентого подхода к межкультурной компетентности (Multicomponent approach of CCC; Bartel-Radic, Giannelloni, 2017) и дополняющим конструктом «Посредничество между людьми с разными интересами» Теста для измерения межкультурной компетентности (Test to Measure Intercultural Competence; Schnabel et al., 2015) в одну шкалу «Управление межкультурным взаимодействием». 
В результате была сформирована теоретическая интегративная модель компетентности, которая легла в основу разработки опросника. Она состояла из девяти конструктов: Межкультурная стабильность, Межкультурная гибкость, Межкультурная открытость, Межкультурный интерес, Отсутствие этноцентризма, Культурная сензитивность, Межкультурная эмпатия, Толерантность к межкультурной неопределенности (Khukhlaev et al., 2020). $\mathrm{Ha}$ основании данной модели были сгенерированы утверждения «Интегративного опросника межкультурной компетентности». Исходным материалом для формулировки утверждений выступали методики измерения межкультурной компетентности, включенные в первичный анализ (Гриценко и др., 2020), инструментарий которых находился в открытом доступе. Так, опросник культурного интеллекта распространяется свободно и даже переведен на русский язык (Солдатова и др., 2018), а Шкала межкультурного адаптационного потенциала ICAPS (Matsumoto et al., 2001) представляет собой инструмент с ключом, закрытым для пользователей, поэтому не могла быть использована нами. Также мы использовали широкий круг опросников, направленных на диагностику более универсальных конструктов (например «открытость»), адаптируя утверждения для контекста межкультурного общения. Из одной методики было использовано не более трех пунктов, многие из них были существенно изменены с целью соответствия нормам русского языка. Ввиду этих изменений содержание опросника является авторским.

Исследование было направлено на проверку внешней и внутренней валидности опросника и проходило в один этап.

\section{Метод}

Выборка. В исследовании приняло участие 1024 респондента, проживающих в настоящее время в России ( $75.9 \%$ женщин, $\mathrm{n}=777)$, от 18 до 65 лет $(\mathrm{M}=$ $33.9, \mathrm{SD}=14.4)$. Из них 383 респондента $(37 \%)$ заняты в сфере образования (83 учителя начальной школы, 25 учителей средней школы, 149 педагогов высшей школы, 126 занимают иные должности в образовании), 111 - работают в области бизнеса (11\%), 81 - заняты в сфере государственного и муниципального управления (8\%).

Остальные респонденты указали иную сферу занятости, не указали профессиональную принадлежность или не имеют в настоящее время какой-либо профессиональной занятости (в том числе в связи с обучением).

$42 \%$ респондентов $(\mathrm{n}=426)$ во время проведения исследования являлись студентами вузов, среди них 156 человек - иностранные студенты, обучающиеся в основном в РУДН и МГППУ (из Италии, Китая и Туркмении) с хорошим владением русским языком.

Все респонденты заполняли «Интегративный опросник межкультурной компетентности» и отвечали на вопросы - маркеры межкультурных достижений. $62 \%$ респондентов $(\mathrm{n}=638)$ также заполняли опросник культурного интеллекта. Педагоги высших и средних учебных заведений, работающие с мигрантами/иностранными студентами $(\mathrm{n}=53 / 94)$, отвечали на вопросы, 
связанные с самоэффективностью и эмоциональным выгоранием от межкультурного взаимодействия. Иностранные студенты дополнительно заполняли опросники, направленные на диагностику их психологической и социокультурной адаптации.

\section{Методики}

«Интегративный опросник межкультурной компетентности». Шкала разработана авторским коллективом под руководством О.Е. Хухлаева. Вопросы были сгенерированы на основании существующих опросников межкультурной компетентности, а также иных инструментов, направленных на изучение индивидуальных особенностей, с ней связанных. Все вопросы были сформулированы так, чтобы они касались именно межкультурной направленности и общения с людьми из других культур. Например, суждение «Я считаю себя легко адаптирующимся человеком» из опросника глобальных компетенций (Global Competencies Inventory; Bird et al., 2010) было изменено на «Я легко адаптируюсь к нормам и правилам другой культуры».

По каждой из девяти шкал теоретической интегративной модели межкультурной компетентности (см. выше) было сгенерировано по 10 пунктов, из которых затем были удалены суждения, понимание которых на русском языке может быть затруднено. В результате был составлен опросник из 70 суждений с пятибалльной шкалой оценки (от 1 - «Полностью не согласен» до 5 «Полностью согласен»), отражающих каждый из девяти конструктов интегративной модели межкультурной компетентности. Количество сгенерированных вопросов превышало необходимое с целью последующего отбора утверждений, обеспечивающих наилучшие психометрические показатели.

Для проверки внешней валидности были использованы следующие измерения.

Вопросы - маркеры межкультурных достижений. Мы использовали четыре вопроса, которые в различных исследованиях межкультурной компетентности используются как конкретные маркеры наличия у человека достижений в области межкультурного взаимодействия: «У вас много друзей другой культуры?» (варианты ответов «Да» и «Нет»), «У вас есть успешный опыт жизни/учебы/работы за рубежом?» (варианты ответов «Да» и «Нет»), «Сколькими языками вы владеете (включая родной/родные языки)? (напишите цифру)», «Сколько стран вы посетили за последние 5 лет? (напишите цифру)».

Расширенная шкала культурного интеллекта позволяет определить выраженность четырех основных компонентов культурного интеллекта (CQ способности индивида эффективно функционировать и взаимодействовать в ситуациях, характеризующихся культурным многообразием) (Ang et al., 2006; Солдатова и др., 2018). Методика состоит из 4 шкал (метакогнитивный, когнитивный, мотивационный и поведенческий компоненты CQ), включающих 37 утверждений с семибалльной шкалой оценки (от 1 - «Полностью не согласен» до $7-$ «олностью согласен»). 
Психологическая адаптация. Использована шкала измерения удовлетворенности собой из опросника MIRIPS (Mutual Intercultural Relations in Plural Societies; MIRIPS, n.d.), переведенного и адаптированного для использования в России (Лебедева, Татарко, 2009). Шкала содержит 9 утверждений с пятибалльной шкалой оценки (от 1 - «Полностью не согласен» до 5 «Полностью согласен»).

Социокультурная адаптация. Мы использовали адаптированную шкалу из опросника MIRIPS (Там же), включающую 21 обратный вопрос (например, «Укажите, пожалуйста, в какой мере вы испытываете в России трудности в установлении и поддержании контактов с людьми»). Респонденту предлагалось 5 вариантов ответов: от 1 - «Абсолютно не согласен» до 5 - «Абсолютно согласен». Далее ответы перекодировались.

Эмоциональное выгорание педагога от межкультурного взаимодействия. Мы использовали шкалу из шести вопросов, разработанную М. Татаром и Г. Горенчиком (Tatar, Horenczyk, 2003) и переведенную Н.А. Лариным (Ларин, 2017), для оценки степени личного и профессионального благополучия педагога, которое зависит от того, как он справляется с трудностями, возникающими в поликультурном классе. Для школьных учителей опросник был направлен на самоанализ работы с детьми-мигрантами, а для преподавателей вузов с иностранными студентами. Респондент мог согласиться или не согласиться с утверждениями, используя 5-балльную шкалу (от 1 - «Полностью не согласен» до 5 - «Полностью согласен»).

Самоэффективность педагога в работе с мигрантами. Мы использовали шкалу из шести вопросов, разработанную М. Татаром и др. (Tatar et al., 2011) для оценки веры учителя в то, что он успешно работает с учениками-мигрантами, в переводе на русский язык О.Е. Хухлаева. Для школьных учителей опросник был направлен на самоанализ работы с детьми-мигрантами, а для преподавателей вузов - с иностранными студентами. Респондент мог согласиться или не согласиться с утверждениями, используя 5-балльную шкалу (от 1 - «Полностью не согласен» до 5 - «Полностью согласен»).

\section{Результаты}

Структура опросника. В первой части опишем результаты эмпирической проверки опросника, созданного на основе интегративной модели межкультурной компетентности, включая последовательность действий по уменьшению количества суждений.

Вначале каждая шкала была проверена на согласованность пунктов с помощью коэффициента альфа Кронбаха. Посредством исключения утверждений и анализа последующих изменений коэффициента альфа должны были быть сформированы более короткие шкалы. Однако пять шкал из девяти представленных в теоретической модели опросника не показали достаточной степени надежности и были исключены из последующего анализа. Эксплораторный факторный анализ (метод вращения Варимакс) также показал, что утверждения, сгенерированные для таких шкал, как «Межкультурная гибкость», 
«Межкультурная открытость», «Культурная сензитивность», «Межкультурная эмпатия» и «Толерантность к межкультурной неопределенности», не составляют отдельных факторов.

Таким образом, проверка факторной структуры опросника осуществлялась на сокращенных четырех шкалах: «Межкультурная стабильность» (индивидуальные особенности личности, которые позволяют человеку быть устойчивым к стрессовым ситуациям межкультурного общения), «Межкультурный интерес» (желание общаться с людьми из других культур, интерес к культуре и культурным различиям), «Отсутствие этноцентризма» (установка на уважение и принятие культурного разнообразия в сочетании с отношением к культурным различиям как к множеству вариантов при отсутствии превосходства той или иной культуры) и «Управление межкультурным взаимодействием» (владение широким спектром коммуникативных навыков, важных при межкультурном общении, обеспечивающих подстройку под собеседника из другой культуры и позволяющих договориться с ним). Конфирматорный факторный анализ с помощью программы AMOS 22.0 продемонстрировал недостаточное соответствие исходным данным и рекомендованным нормам по некоторым показателям (Hu, Bentler, 1999) (см. таблицу 1, модель 1).

Далее были проанализированы индексы модификации на наличие ковариаций ошибок между различными суждениями. Анализ пунктов с выявленной сильной связью показал, что данные суждения схожи по смысловой нагрузке (например, «После общения с человеком другой культуры меня часто терзает чувство вины» и «После общения с людьми из другой культуры я чувствую себя совершенно разбитым», $\left.\chi^{2}=45.21\right)$. В результате в модель были включены четыре ковариации. Для данного варианта был повторно проведен конфирматорный факторный анализ, который показал, что модель демонстрирует лучшее соответствие эмпирическим данным (см. таблицу 1, модель 2). При этом показатель TLI (индекс Тьюкера-Льюиса), являющийся релятивистским индексом соответствия, независимым от размера выборки (Marsh et al., 1988), немного не достигает требуемой нормы 0.95. Однако если рассматривать индексы соответствия в сочетании друг с другом, то видно, что параметры модели выходят за рамки риска возникновения ошибок (при TLI $\leqslant 0.91$ показатель SRMR $\geqslant 0.07)$ и свидетельствуют о наличии риска недостоверной

Таблица 1

Показатели Интегративного опросника межкультурной компетентности

\begin{tabular}{|l|c|c|c|c|c|c|c|c|c|c|c|c|}
\hline \multicolumn{1}{|c|}{ Модели } & $\boldsymbol{\chi}^{2}$ & $\boldsymbol{p}$ & $\mathbf{d f}$ & $\boldsymbol{\chi}^{2} / \mathbf{d f}$ & TLI & RMSEA & GFI & AGFI & CFI & AIC & BIC & SRMR \\
\hline № 1. 4 шкалы & 584.72 & 0.00 & 129 & 4.55 & 0.88 & 0.06 & 0.94 & 0.91 & 0.90 & 668.72 & 876.33 & 0.05 \\
\hline $\begin{array}{l}\text { № 2. 4 шкалы с } \\
\text { ковариациями }\end{array}$ & 448.31 & 0.00 & 125 & 3.58 & 0.91 & 0.05 & 0.95 & 0.93 & 0.93 & 450.31 & 767.70 & 0.05 \\
\hline $\begin{array}{l}\text { № 3. 4 шкалы с } \\
\text { ковариациями и } \\
\text { общим фактором } \\
\text { второго порядка }\end{array}$ & 564.25 & 0.00 & 127 & 4.44 & 0.89 & 0.06 & 0.94 & 0.92 & 0.90 & 652.25 & 869.74 & 0.06 \\
\hline
\end{tabular}


оценки (Hu, Bentler, 1999). Также модель соотносится с другим сочетанием критериев соответствия: RMSEA $\leqslant 0.5$ и SRMR $\leqslant 0.6$. Таким образом, можно говорить о том, что параметры модели соответствуют эмпирическим данным.

Распределение пунктов по шкалам и стандартизированные факторные нагрузки представлены на рисунке 1.

Была проверена дополнительная гипотеза о существовании вложенной модели с пятью шкалами и одним вторичным фактором - общим показателем межкультурной компетентности (см. таблицу 1, модель 3). Она продемонстрировала менее приемлемые показатели соответствия и в дальнейшем не участвовала в анализе.

Данные о надежности шкал, средние значения и стандартные отклонения представлены в таблице 2 и свидетельствуют о хороших показателях надежности методики.

Рисунок 1

\section{Структура Интегративного опросника межкультурной компетентности}

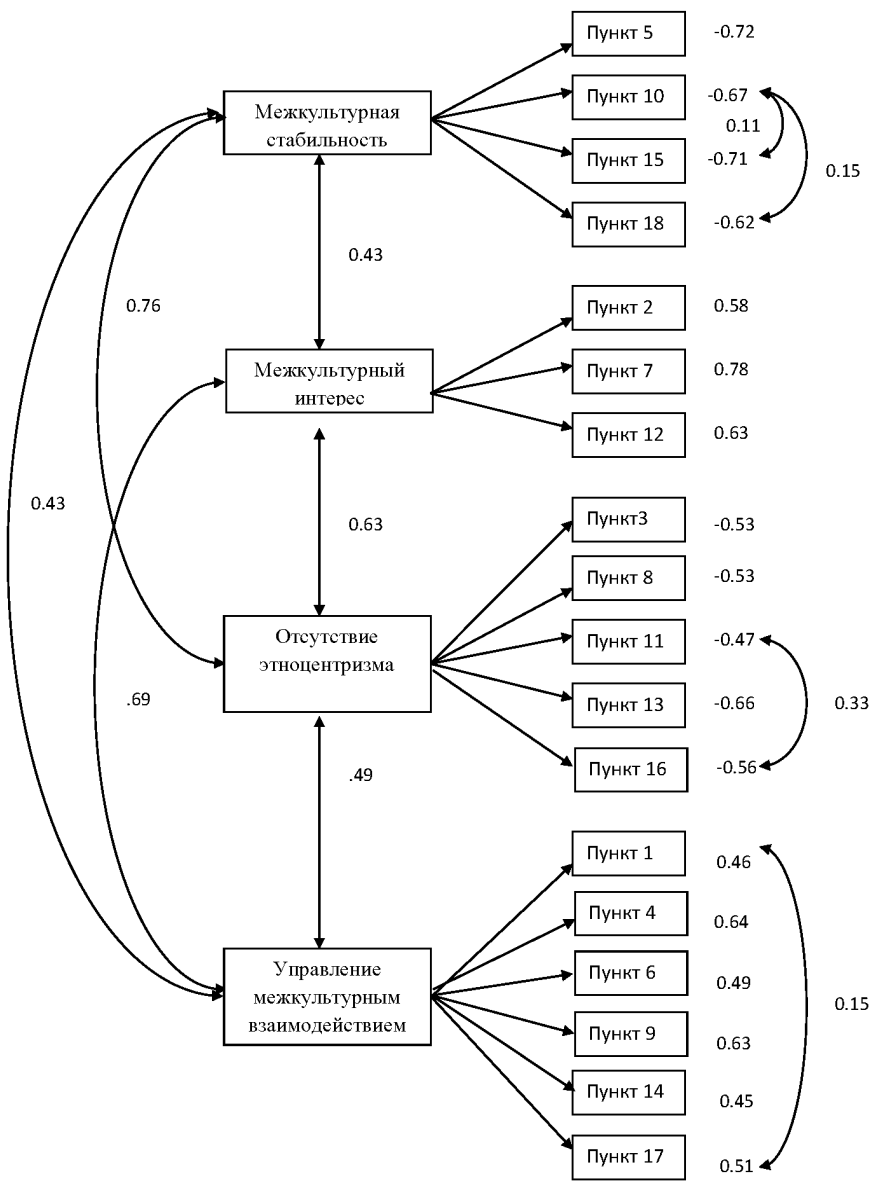


Структурная валидность опросника. Для дальнейшей проверки структурной валидности четырехфакторной структуры опросника был проведен мультигрупповой факторный анализ (таблица 3). Респонденты были разделены сначала на мужчин $(\mathrm{n}=247)$ и женщин $(\mathrm{n}=777)$, а затем на людей до 33 лет включительно $(\mathrm{n}=577)$ и старше 34 лет $(\mathrm{n}=447)$. В первом случае параметры межгруппового сравнения показывают, что опросник обладает конфигурационной, метрической и скалярной инвариантностью. При возрастном сравнении обнаружено, что опросник демонстрирует конфигурационную и скалярную, но не метрическую инвариантность ( $\triangle$ CFI больше 0.01) (Cheung, Rensvold, 2002). Несмотря на данные о том, что факторные нагрузки суждений могут быть различны для людей разного возраста (отсутствие метрической инвариантности), достижение скалярной инвариантности, показывающей, что нагрузки разных суждений вносят эквивалентный вклад в латентную переменную, свидетельствует о противоречивых перспективах возрастных сравнений по шкалам опросника. Этот вопрос требует дальнейшего изучения.

Внешняя валидность. Проверка внешней валидности опросника состояла из нескольких этапов, осуществлявшихся на различных выборках. Для ее

Таблица 2

Интеркорреляции и описательные статистики шкал

Интегративного опросника межкультурной компетентности

\begin{tabular}{|l|c|c|c|c|c|c|c|c|}
\hline \multicolumn{1}{|c|}{ Шшкалы } & $\mathbf{n}$ & $\mathbf{M}$ & $\mathbf{S D}$ & $\boldsymbol{\alpha}$ & $\mathbf{1}$ & $\mathbf{2}$ & $\mathbf{3}$ & $\mathbf{4}$ \\
\hline $\begin{array}{l}\text { Межкультрная } \\
\text { стабильность }\end{array}$ & 1021 & 3.24 & 0.74 & 0.77 & 1 & $0.29^{* *}$ & $0.55^{* *}$ & $0.31^{* *}$ \\
\hline Межкультурный интерес & 1017 & 4.05 & 0.72 & 0.71 & $0.29^{* *}$ & 1 & $0.43^{* *}$ & $0.49^{* *}$ \\
\hline Отсутствие этноцентризма & 1001 & 3.13 & 0.64 & 0.71 & $0.55^{* *}$ & $0.43^{* *}$ & 1 & $0.34^{* *}$ \\
\hline $\begin{array}{l}\text { Управление межкультурным } \\
\text { взаимодействием }\end{array}$ & 1008 & 3.83 & 0.59 & 0.70 & $0.31^{* *}$ & $0.49^{* *}$ & $0.34^{* *}$ & 1 \\
\hline
\end{tabular}

$* * p<0.01$.

Таблица 3

Результаты мультигруппового конфирматорного факторного анализа

\begin{tabular}{|c|c|c|c|c|c|c|c|c|c|c|}
\hline Группы & Модель & $\chi^{2}$ & df & $\chi^{2} / \mathrm{df}$ & TLI & RMSEA & CFI & AIC & SRMR & $\triangle \mathrm{CFI}$ \\
\hline \multirow{3}{*}{$\begin{array}{l}\text { Гендерные } \\
\text { группы } \\
\text { (мужчины, } \\
\text { женщины) }\end{array}$} & $\begin{array}{l}\text { Конфигурационная } \\
\text { инвариантность }\end{array}$ & 605.38 & 250 & 2.42 & 0.906 & 0.037 & 0.923 & 789.38 & 0.064 & - \\
\hline & $\begin{array}{l}\text { Метрическая } \\
\text { инвариантность }\end{array}$ & 590.35 & 264 & 2.26 & 0.916 & 0.035 & 0.928 & 754.35 & 0.074 & 0.005 \\
\hline & $\begin{array}{l}\text { Скалярная } \\
\text { инвариантность }\end{array}$ & 633.80 & 275 & 2.30 & 0.913 & 0.036 & 0.922 & 767.80 & 0.076 & 0.006 \\
\hline \multirow{3}{*}{$\begin{array}{l}\text { Возрастные } \\
\text { группы (до } 33 \\
\text { лет, от } 34 \text { и } \\
\text { старше) }\end{array}$} & $\begin{array}{l}\text { Конфигурационная } \\
\text { инвариантность }\end{array}$ & 644.77 & 250 & 2.66 & 0.890 & 0.400 & 0.910 & 848.79 & 0.053 & - \\
\hline & \begin{tabular}{|l|} 
Метрическая \\
инвариантность
\end{tabular} & 589.92 & 264 & 2.23 & 0.918 & 0.350 & 0.930 & 745.92 & 0.055 & 0.020 \\
\hline & $\begin{array}{l}\text { Скалярная } \\
\text { инвариантность }\end{array}$ & 614.76 & 275 & 2.23 & 0.918 & 0.350 & 0.927 & 748.76 & 0.055 & 0.003 \\
\hline
\end{tabular}


определения были выбраны методики, измеряющие свойства, с которыми, согласно теоретическим представлениям, должна быть связана межкультурная компетентность. Методика измерения культурного интеллекта позволяет определить способности индивида эффективно функционировать и взаимодействовать в ситуациях, характеризующихся культурным многообразием (Ang et al., 2006). Вопросы - маркеры межкультурных достижений - отражают наличие у человека конкретных успехов в области межкультурного взаимодействия, что должно являться прямым следствием межкультурной компетентности. Кроме того, межкультурная компетентность в конкретной социальной ситуации должна предсказывать личную и/или профессиональную успешность в культурно иной среде. Для иностранных студентов показателями успешности могут выступать критерии их психологической и социокультурной адаптации (Лебедева, Татарко, 2009), а для педагогов, работающих с учащимися других культур, - самоэффективность и низкое эмоциональное выгорание (Tatar, Horenczyk, 2003; Tatar et al., 2011). Описательная статистика и корреляции представлены в таблицах 4-6.

Все шкалы интегративного опросника межкультурной компетентности демонстрируют корреляции со всеми компонентами культурного интеллекта CQ. C первым вопросом-маркером межкультурных достижений «Сколько стран вы посетили за последние 5 лет?» крайне слабо связаны все шкалы опросника, кроме шкалы «Отсутствие этноцентризма» (таблица 4).

Выявление связи показателей Интегративного опросника межкультурной компетентности с ответами на второй-четвертый вопросы-маркеры межкультурных достижений проводилось с помощью серии однофакторных дисперсионных анализов (ANOVA). Средние значения всех показателей представлены в таблице 5. Респонденты, сообщившие о наличии успешного опыта жизни, учебы или работы за рубежом, демонстрируют более высокий уровень межкультурной стабильности $(\mathrm{F}=5.06, p=0.02)$, межкультурного интереса $(\mathrm{F}=24.02$, $p=0.00)$ и способностей к управлению межкультурным взаимодействием ( $\mathrm{F}=7.19$, $p=0.01)$. Те из испытуемых, кто согласился с тем, что у них много друзей из другой культуры, демонстрируют более высокие показатели по всем шкалам Интегративного опросника межкультурной компетентности $(\mathrm{F}=9.23 / 95.36$ / $26.90 / 18.68, p \leqslant 0.002)$. Респонденты, владеющие тремя и более языками (включая родной), показывают более высокую межкультурную стабильность $(\mathrm{F}=13.67, p=0.00)$, а те, кто говорят только на одном языке, демонстрируют более низкий уровень межкультурного интереса $(\mathrm{F}=7.39, p=0.00)$.

На трех подвыборках проверялось наличие взаимосвязей шкал Интегративного опросника межкультурной компетентности с показателями межкультурной эффективности, имеющими отношение к конкретной социальной ситуации (таблица 6).

У иностранных студентов, обучающихся в вузах Москвы, все шкалы Интегративного опросника межкультурной компетентности связаны с выраженностью их социокультурной адаптации. С эффективностью психологической адаптации связаны шкалы «Межкультурный интерес» и «Управление межкультурным взаимодействием». 
Таблица 4

Корреляции между компонентами культурного интеллекта CQ, вопросом-маркером межкультурных достижений и показателями Интегративного опросника межкультурной компетентности

\begin{tabular}{|l|c|c|c|c|c|c|c|c|}
\hline & $\mathbf{n}$ & $\mathbf{M}$ & $\mathbf{S D}$ & $\boldsymbol{\alpha}$ & $\mathbf{M C т}$ & $\mathbf{M И}$ & ОЭЦ & УМВ \\
\hline Мотивационный CQ & 638 & 5.11 & 0.95 & 0.75 & $0.42^{* *}$ & $0.57^{* *}$ & $0.43^{* *}$ & $0.64^{* *}$ \\
\hline Когнитивный CQ & 624 & 4.80 & 0.88 & 0.79 & $0.23^{* *}$ & $0.35^{* *}$ & $0.20^{* *}$ & $0.49^{* *}$ \\
\hline Метакогнитивный CQ & 631 & 5.16 & 0.93 & 0.81 & $0.31^{* *}$ & $0.37^{* *}$ & $0.29^{* *}$ & $0.69^{* *}$ \\
\hline Поведенческий CQ & 637 & 4.81 & 0.99 & 0.77 & $0.21^{* *}$ & $0.35^{* *}$ & $0.20^{* *}$ & $0.59^{* *}$ \\
\hline $\begin{array}{l}\text { Сколько стран вы посети- } \\
\text { ли за последние 5 лет? }\end{array}$ & 917 & 2.47 & 20.15 & - & $0.11^{* *}$ & $0.11^{* *}$ & 0.12 & $0.11^{* *}$ \\
\hline
\end{tabular}

** $p<0.01$.

Примечание. Здесь и далее: МСт - Межкультурная стабильность; МИ - Межкультурный интерес; ОЭЦ - Отсутствие этноцентризма; УМВ - Управление межкультурным взаимодействием.

Таблица 5

Средние значения показателей Интегративного опросника межкультурной компетентности в связи с ответами на вопросы - маркеры межкультурных достижений (ANOVA)

\begin{tabular}{|c|c|c|c|c|c|c|c|c|c|}
\hline \multirow{2}{*}{ Вопросы } & \multirow{2}{*}{ Ответы } & \multicolumn{2}{|c|}{ МСт } & \multicolumn{2}{|c|}{ МИ } & \multicolumn{2}{|c|}{ ОЭЦ } & \multicolumn{2}{|c|}{ УМВ } \\
\hline & & $\mathrm{M}$ & SD & $\mathrm{M}$ & SD & $\mathrm{M}$ & SD & $\mathrm{M}$ & SD \\
\hline \multirow{2}{*}{$\begin{array}{l}\text { У вас есть успеш- } \\
\text { ный опыт жизни/ } \\
\text { учебы/работы за } \\
\text { рубежом? }\end{array}$} & Да & $1.80 *$ & 0.80 & $4.19 * *$ & 0.65 & 3.15 & 0.66 & $3.90 * *$ & 0.58 \\
\hline & Нет & 1.70 & 0.66 & 3.96 & 0.75 & 3.12 & 0.63 & 3.80 & 0.58 \\
\hline \multirow{2}{*}{$\begin{array}{l}\text { У вас много друзей } \\
\text { из другой культуры? }\end{array}$} & Да & $3.33 * *$ & 0.71 & $4.25^{* *}$ & 0.62 & $3.23 * *$ & 0.63 & $3.92 * *$ & 0.58 \\
\hline & Нет & 3.19 & 0.72 & 3.82 & 0.77 & 3.02 & 0.64 & 3.75 & 0.57 \\
\hline \multirow{3}{*}{$\begin{array}{l}\text { Сколькими языками } \\
\text { вы владеете? }\end{array}$} & 1 & 3.11 & 0.60 & $3.90^{*}$ & 0.78 & 3.12 & 0.56 & 3.77 & 0.52 \\
\hline & 2 & 3.12 & 0.63 & 4.03 & 0.71 & 3.17 & 0.61 & 3.85 & 0.60 \\
\hline & 3 & $3.33^{* *}$ & 0.85 & 4.15 & 0.69 & 3.09 & 0.71 & 3.85 & 0.59 \\
\hline
\end{tabular}

${ }^{*} p<0.05,{ }^{* *} p<0.01$.

Все шкалы Интегративного опросника межкультурной компетентности отрицательно связаны с эмоциональным выгоранием учителя от межкультурного взаимодействия. Самоэффективность учителя в работе с детьми-мигрантами связана со шкалой «Управление межкультурным взаимодействием».

У педагогов высшей школы ощущение их самоэффективности при работе с иностранными студентами связано с самооценкой управления межкультурным взаимодействием, а также с межкультурным интересом. Эмоциональное выгорание преподавателей вузов от межкультурного общения связано со шкалами «Межкультурная стабильность» и «Межкультурный интерес». 
Таблица 6

Корреляции между показателями Интегративного опросника межкультурной компетентности и методиками проверки внешней валидности у иностранных студентов и педагогов

\begin{tabular}{|l|c|c|c|c|c|c|c|c|}
\hline \multicolumn{1}{|c|}{ Шкалы методик } & $\mathbf{n}$ & $\mathbf{M}$ & $\mathbf{S D}$ & $\boldsymbol{\alpha}$ & $\mathbf{M C т}$ & $\mathbf{M И}$ & ОЭЦ & УМВ \\
\hline $\begin{array}{l}\text { Психологическая } \\
\text { адаптация }\end{array}$ & 156 & 3.65 & 0.58 & 0.84 & 0.12 & $0.36^{* *}$ & 0.10 & $0.42^{* *}$ \\
\hline $\begin{array}{l}\text { Социокультурная } \\
\text { адаптация }\end{array}$ & 156 & 2.84 & 0.65 & 0.92 & $0.48^{* *}$ & $0.30^{* *}$ & $0.49^{* *}$ & $0.37^{* *}$ \\
\hline $\begin{array}{l}\text { Эмоциональное } \\
\text { выгорание учителя } \\
\begin{array}{l}\text { от межкультурного } \\
\text { взаимодействия }\end{array}\end{array}$ & 53 & 2.29 & 0.61 & 0.73 & $-0.48^{* *}$ & $-0.49^{* *}$ & $-0.54^{* *}$ & $-0.47^{* *}$ \\
\hline $\begin{array}{l}\text { Самоэффективность } \\
\text { учителя в работе с } \\
\text { детьми-мигрантами }\end{array}$ & 53 & 3.93 & 0.48 & 0.83 & 0.09 & 0.10 & -0.06 & $0.32^{*}$ \\
\hline $\begin{array}{l}\text { Эмоциональное } \\
\text { выгорание педагога } \\
\text { вуза от межкультур- } \\
\text { ного взаимодействия }\end{array}$ & 94 & 2.19 & 0.52 & 0.72 & $-0.39 * *-0.32^{* *}$ & -0.12 & -0.18 \\
\hline $\begin{array}{l}\text { Самоэффективность } \\
\text { педагога вуза в рабо- } \\
\text { те с иностранными } \\
\text { студентами }\end{array}$ & 94 & 3.90 & 0.53 & 0.79 & 0.14 & $0.43^{* *}$ & 0.04 & $0.48^{* *}$ \\
\hline
\end{tabular}

${ }^{*} p<0.05,{ }^{* *} p<0.01$.

\section{Обсуждение}

В данном исследовании была описана процедура разработки методики «Интегративный опросник межкультурной компетентности», проанализированы ее структура и валидность.

Было показано, что настоящая методика включает четыре субшкалы, отражающие различные аспекты межкультурной компетентности, понимаемой как способность личности эффективно функционировать при общении с представителями различных культур и в разных культурных средах (Whaley, Davis, 2007). Таким образом, эмпирическое подтверждение было найдено только по четырем из теоретически обоснованных девяти шкал интегративного измерения межкультурной компетентности. Возможно, это связано с тем, что данные шкалы также дублировали друг друга. Отчасти этот факт подтверждается тем, что в шкалу «Отсутствие этноцентризма» было введено одно суждение, сгенерированное для шкалы «Межкультурная открытость», что существенно улучшило психометрические показатели опросника. С другой стороны, нельзя исключить вероятность культурной специфичности определенных измерений межкультурной компетентности, выявленных в одной 
культурной среде, но не обнаруженных в российской выборке. Кроме того, вероятно, данный результат мог быть следствием сознательно выбранного авторского подхода. Как было отмечено, все аспекты теоретической модели межкультурной компетентности были сформулированы как культурно-специфические (например, «толерантность к межкультурной неопределенности»). В соответствии с этим сгенерированы и пункты опросника. Однако вполне вероятно, что некоторые составляющие, включаемые авторами в межкультурную компетентность, не являются специфичными по отношению к ней и не могут быть измерены применительно только к ситуации межкультурного общения. Так, толерантность к неопределенности, по всей видимости, неэффективно измерять исключительно в межкультурном контексте, а лучше использовать устоявшиеся универсальные методы ее оценки. Таким образом, можно говорить, что эмпирически подтвержденные четыре шкалы опросника отражают четыре специфических компонента межкультурной компетентности, имеющих отношение непосредственно к межкультурному общению.

Выявленные корреляции всех шкал Интегративного опросника межкультурной компетентности со всеми компонентами культурного интеллекта CQ показывают сопоставимость измеряемых конструктов. Определение культурного интеллекта как «способности индивида эффективно функционировать и взаимодействовать в ситуациях, характеризующихся культурным многообразием» (Солдатова и др., 2018, с. 512), по сути, соответствует определению межкультурной компетентности, используемому в исследовании. Однако схожесть в данном случае не обязательно свидетельствует о прямом соответствии, так как данные определения построены путем обозначения результата - эффективного функционирования в межкультурной среде. При этом подходы к тому, как и с помощью чего будет обеспечен данный результат, могут быть разные, что и подтверждается разной выраженностью взаимных корреляций двух методик.

Наиболее выражены взаимосвязи $(r \geqslant 0.5)$ шкалы «Управление межкультурным взаимодействием» со всеми компонентами CQ, кроме Когнитивного и шкалы «Межкультурный интерес» с Мотивационным CQ. «Интегративный опросник межкультурной компетентности» не включает знаниевого компонента. Этим объясняются более низкие корреляции его шкал с Когнитивным компонентом CQ, включающим в себя общие и контекстные знания о культурных системах. Согласно современным подходам к психологии способностей, знания являются не их составляющими, а скорее средством, условием их реализации (Шадриков, 2010). С нашей точки зрения, использование знаниевого компонента в измерении межкультурных способностей эффективно только в формате теста ситуационных суждений (Личутина, 2017), когда знания неразрывно связаны с реализацией их на практике в конкретном выборе. В области межкультурной компетентности такая задача может быть реализована в формате культурного ассимилятора (Bhawuk, 2001), используемого отдельными специалистами для измерения межкультурной компетентности (Bartel-Radic, Giannelloni, 2017; Schnabel et al., 2015).

B наибольшей степени со шкалами Интегративного опросника межкультурной компетентности связан Мотивационный CQ, включающий интерес к 
межкультурному разнообразию, представление о возможной выгоде от межкультурного общения и уверенность в собственной эффективности в кросскультурной среде. По содержанию конструкта Мотивационный $\mathrm{CQ}$ тесно пересекается со шкалами интегративной модели межкультурной компетентности, вошедшими в опросник, что и обуславливает их взаимосвязь.

Метакогнитивный CQ (планирование, осознание и контроль над межкультурным общением) и Поведенческий $\mathrm{CQ}$ (гибкость и точность в межкультурном общении) наиболее сильно связаны со шкалой опросника «Управление межкультурным взаимодействием» также по причине высокой содержательной схожести изучаемых конструктов.

В целом можно сказать, что Интегративный опросник межкультурной компетентности является средством измерения, отчасти схожим, а отчасти отличающимся от «Расширенной шкалы культурного интеллекта». Основная специфика изучаемого опросника связана со шкалами «Отсутствие этноцентризма» и «Межкультурная стабильность», а схожесть - со шкалой «Управление межкультурным взаимодействием».

Выявлено, что люди, демонстрирующие более высокие показатели по ряду шкал опросника, отличаются большим количеством конкретных межкультурных достижений: у них больше друзей, принадлежащих другой культуре, они знают больше иностранных языков и с большей вероятностью имеют успешный опыт жизни, учебы или работы за рубежом. Наибольший вклад в достижение данных результатов вносят «Межкультурная стабильность» и «Межкультурный интерес», т.е. сочетание позитивного настроя на межкультурное общение со стрессоустойчивостью в межкультурном взаимодействии.

Взаимосвязи шкал опросника с показателями адаптации иностранных студентов носят предсказуемый характер. Социокультурная адаптация у мигрантов (в том числе и иностранных студентов) зависит от степени их включенности в контакты с представителями принимающей культуры и межгрупповых установок (Лебедева, 2009). Высокий уровень межкультурной компетентности по всем шкалам опросника во многом будет определять количество и качество межкультурных контактов у студента, обучающегося за рубежом.

Психологическая адаптация мигрантов зависит от событий жизни и социальной поддержки (Там же). Наличие высоких показателей по шкале «Межкультурный интерес» свидетельствует о мотивации на принятие иностранными студентами поддержки от представителей принимающей культуры, а шкала «Управление межкультурным взаимодействием» отражает способности индивида эту поддержку получить.

Высокий уровень межкультурной компетентности по всем шкалам опросника связан с более низкой выраженностью эмоционального выгорания. Эмоциональное выгорание определяется как психологический синдром, возникающий в ответ на хронический профессиональный стресс и характеризующийся истощением, отстраненностью от работы и циничным к ней отношением, а также ощущением профессиональной некомпетентности (Maslach et al., 2001). Показано, что отношение педагогов к культурному разнообразию в образовательной среде как к проблеме повышает риски эмоционального 
выгорания от межкультурного взаимодействия, а обозначение культурных различий в образовании как ценности - снижает (Gutentag et al., 2018). Очевидно, что межкультурная компетентность во всех своих аспектах обеспечивает для педагога эффективный барьер на пути эмоционального выгорания.

Самоэффективность педагога при работе в культурно разноообразной среде связана преимущественно со шкалой опросника «Управление межкультурным взаимодействием». Педагог с более высокими показателями по данной шкале отличается развитой способностью к планированию и контролю результатов межкультурной коммуникации. Это не может не приводить его к ощущению собственной способности выполнять требуемые задачи в работе с учащимися другой культуры.

Интегративный опросник межкультурной компетентности является комплексной методикой, интегрирующей ряд показателей межкультурной компетентности, и может быть эффективно использован для исследования предпосылок межкультурной успешности на российских выборках.

При этом необходимо отметить следующие ограничения исследования. Отсутствие метрической инвариантности опросника при сравнении людей разного возраста требует дальнейшего изучения, в том числе и с более узкими возрастными диапазонами. Также необходимы межгрупповые сравнения представителей разных профессиональных сфер.

Кроме того, было найдено эмпирическое подтверждение только четырем из теоретически обоснованных девяти шкал измерения межкультурной компетентности. Возможно, это связано с недоработками в процессе генерации пунктов опросника и требует использования других подходов для создания шкал, измеряющих данные конструкты.

\section{Литература}

Гриценко, В. В., Павлова, О. С., Ткаченко, Н. В., Усубян, Ш. А., Хухлаев, О. Е., Шорохова, В. А. (2020). Анализ зарубежных эмпирических моделей межкультурной компетентности и методик для ее оценки. Современная зарубежная психология, 1(9), 103-113. doi:10.17759/jmfp.2020090111

Ларин, Н. А. (2017). Феномен эмоционального выгорания при межкультурном взаимодействии. Психология и психотехника, 3, 1-9. Режим доступа: https://nbpublish.com/library_read_article.php?id=23962

Лебедева, Н. М. (2009). Теоретические подходы к исследованию взаимных установок и стратегий межкультурного взаимодействия мигрантов и населения России. В кн. Н. М. Лебедева, А. Н. Татарко (ред.), Стратегии межкультурного взаимодействия мигрантов и населения России (с. 10-62). М.: РУДН.

Лебедева, Н. М., Татарко, А. Н. (ред.). (2009). Стратегии межкультурного взаимодействия мигрантов и населения России. М.: РУДН.

Личутина, Э. И. (2017). Тест ситуативных суждений как метод диагностики решений профессиональных проблем. Экономика и менеджмет инноващионных технологий, 1. Режим доступа: http://ekonomika.snauka.ru/2017/01/13784 
Солдатова, Г. У., Чигарькова, С. В., Рассказова, Е. И. (2018). Апробация русскоязычной версии расширенной шкалы культурного интеллекта. Психология. Журнал Высшей школь экономи$\kappa и, 3(15), 510-526$.

Хухлаев, О. Е., Чибисова, М. Ю. (2010). Теоретические и практические вопросы межкультурной коммуникации: современные тенденции. Психологическая наука и образование, 5(2). Режим доступа: http://psyjournals.ru/psyedu_ru/2010/n5/Huhlaev_Chibisova.shtml

Шадриков, В. Д. (2010). Вопросы психологической теории способностей. Психология. Журнал Высшей школь экономики, 3(7), 41-56.

Ссылки на зарубежные источники см. в разделе References после англоязычного блока.

\section{Интегративный опросник межкультурной компетентности}

Приложение

Просим ответить на несколько вопросов, касающихся вашего общения с людьми других культур. Это могут быть иностранцы, люди других национальностей и/или этнических групп. Людей других культур мы встречаем, не только оказавшись за рубежом; в нашей многонациональной стране каждый ежедневно имеет возможность общаться с ними.

Оцените, насколько вы согласны с каждым утверждением.

\begin{tabular}{|c|c|c|c|c|}
\hline $\begin{array}{c}\text { Полностью } \\
\text { согласен }\end{array}$ & $\begin{array}{c}\text { Скорее } \\
\text { согласен }\end{array}$ & $\begin{array}{c}\text { В чем-то согласен, } \\
\text { в чем-то нет }\end{array}$ & $\begin{array}{c}\text { Скорее } \\
\text { не согласен }\end{array}$ & $\begin{array}{c}\text { Полностью } \\
\text { не согласен }\end{array}$ \\
\hline 5 & 4 & 3 & 2 & 1 \\
\hline
\end{tabular}

1. Я уверен, что могу эффективно работать с людьми различных культур.

2. Мне нравится общаться с людьми других культур.

3. Я не буду общаться с человеком другой культуры, если он действует, исходя из своих культурных норм.

4.В межкультурном общении я стараюсь принимать во внимание мнение каждой стороны и только потом принимать решение.

5. Когда я общаюсь с людьми другой культуры, нервы у меня напряжены до предела.

6. Если у меня планируется важная встреча с человеком другой культуры, я пытаюсь представить, какие могут быть культурные различия между нами.

7. Мне нравится знакомиться с людьми других культур.

8. Я не буду общаться с человеком другой культуры, если ее традиции мне чужды.

9. Я проверяю правильность моего понимания другой культуры в процессе межкультурного общения.

10. После общения с людьми другой культуры я чувствую себя совершенно разбитым.

11. Есть такие культуры, к которым я испытываю презрение.

12. Мне нравится общаться с людьми другой культуры, которая существенно отличается от моей.

13. Я доверяю только людям моей культуры. 
14. Я корректирую свои представления о другой культуре в процессе взаимодействия с ее носителями.

15. От межкультурного общения я не жду ничего хорошего.

16. Есть такие культуры, среди которых - почти все плохие люди.

17. Я могу преодолевать трудности, возникающие при общении с людьми другой культуры.

18. После общения с человеком другой культуры меня терзает чувство вины.

\section{Ключ:}

Межкультурная стабильность $*$ : 5, 10, 15, 18

Межкультурный интерес: 2, 7, 12

Отсутствие этночентризма* : 3, 8, 11, 13, 16

Управление межкультурным взаимодействием: 1, 4, 6, 9, 14, 17

* Обратная шкала.

Хухлаев Олег Евгеньевич - заведующий кафедрой, кафедра этнопсихологии и психологических проблем поликультурного образования, Московский государственный психологопедагогический университет, кандидат психологических наук.

Сфера научных интересов: кросс-культурная психология, психология межгрупповых отношений, социально-психологический тренинг.

Контакты: huhlaevoe@mgppu.ru

Гриценко Валентина Васильевна - профессор, кафедра этнопсихологии и психологических проблем поликультурного образования, Московский государственный психологопедагогический университет, доктор психологических наук.

Сфера научных интересов: кросс-культурная психология, психология миграции, социально-психологическая адаптация.

Контакты: gritsenko2006@yandex.ru

Макарчук Анна Владимировна - программный директор, Федеральный научно-методический центр в области психологии и педагогики толерантности, кандидат психологических наук.

Сфера научных интересов: межкультурный тренинг, психология межкультурной коммуникации, психология и педагогика толерантности.

Контакты: anna.m@tolerancecenter.ru

Павлова Ольга Сергеевна - доцент, кафедра этнопсихологии и психологических проблем поликультурного образования, Московский государственный психолого-педагогический университет, кандидат психологических наук.

Сфера научных интересов: кросс-культурная психология, психология религии, кросс-культурные технологии психологической помощи.

Контакты: os_pavlova@mail.ru

Ткаченко Наталья Владимировна - доцент, кафедра этнопсихологии и психологических проблем поликультурного образования, Московский государственный психолого-педагогический университет, кандидат психологических наук.

Сфера научных интересов: кросс-культурная психология, психология межгрупповых отношений, поликультурное образование, психологическое сопровождение исследовательской деятельности учащихся, полевая этнопсихология.

Контакты: tkachenkonv@mgppu.ru 
Усубян Шушаник Араевна - аспирант, кафедра этнопсихологии и психологических проблем поликультурного образования, Московский государственный психолого-педагогический университет.

Сфера научных интересов: кросс-культурная психология, психология межгрупповых отношений, обучение за рубежом.

Контакты: usubyansha@mgppu.ru

Шорохова Валерия Альбертовна - преподаватель, кафедра этнопсихологии и психологических проблем поликультурного образования, Московский государственный психологопедагогический университет, кандидат психологических наук.

Сфера научных интересов: кросс-культурная психология, психология религии.

Контакты: shorohovava@mgppu.ru

\title{
Development and Adaptation of the Integrative Intercultural Competence Survey
}

\author{
O.E. Khukhlaev ${ }^{a}$, V.V. Gritsenko ${ }^{a}$, A.V. Makarchuk ${ }^{b}$, O.S. Pavlova ${ }^{a}$, N.V. Tkachenko ${ }^{a}$, \\ Sh.A. Usubian ${ }^{a}$, V.A. Shorokhova ${ }^{a}$
}

\begin{abstract}
${ }^{a}$ Moscow State University of Psychology and Education, 29 Sretenka Str., Moscow, 127051, Russian Federation

${ }^{b}$ Federal research and methodology center for tolerance psychology and education, 11 Obraztsova Str., Moscow, 127055, Russian Federation
\end{abstract}

\begin{abstract}
The paper presents the development and the results of testing a new tool Integrative Intercultural Competency Questionnaire, aimed at studying the ability to function effectively in an intercultural communication context. The questionnaire was created on the basis of the integration of 52 constructs from 14 methods for measuring intercultural competence. The research $(\mathrm{N}=1024)$ revealed that the tool contains four subscales: Intercultural Stability (individual personality characteristics that allow a person to be resistant to stressful situations of intercultural communication), Intercultural Interest (desire to communicate with people from other cultures, interest in culture and cultural differences), Lack of Ethnocentrism (respect and acceptance of cultural diversity) and Management of Intercultural Interaction (wide range of communication skills, important for intercultural communication). The subscales have good internal consistency and invariance with some limitations in comparing people of different ages. The research also demonstrated the external validity of the tool. The subscales of the Integrative Intercultural Competency Questionnaire are positively associated with the Extended Cultural Intelligence Scale. People who demonstrate higher rates on individual scales of the questionnaire are distinguished by a large number of specific intercultural achievements. Correlations of the subscales with indicators of adaptation of foreign students, emotional burnout, and self-efficacy among teachers working in a multicultural environment are observed.
\end{abstract}

Keywords: intercultural competence, intercultural communication, cultural intelligence. 


\section{References}

Ang, S., Van Dyne, L., \& Koh, C. (2006). Personality correlates of the four-factor model of cultural intelligence. Group and Organization Management, 31, 100-123. doi:10.1177/1059601105275267

Bartel-Radic, A., \& Giannelloni, J. L. (2017). A renewed perspective on the measurement of cross-cultural competence: an approach through personality traits and cross-cultural knowledge. European Management Journal, 35(5), 632-644. doi:10.1016/j.emj.2017.02.003

Bhawuk, D. P. S. (2001). Evolution of culture assimilators: Toward theory-based assimilators. International Journal of Intercultural Relations, 25(2), 141-163.

Bird, A., Mendenhall, M., Stevens, M., \& Oddou, G. (2010). Defining the content domain of intercultural competence for global leaders. Journal of Managerial Psychology, 25(8), 810-828.

Cheung, G., \& Rensvold, R. (2002). Evaluating Goodness-of-Fit Indexes for testing measurement invariance. Structural Equation Modeling, 9(2), 233-255.

Dollwet, M., \& Reichard R. (2014). Assessing cross-cultural skills: validation of a new measure of cross-cultural psychological capital. The International Journal of Human Resource Management, 25(12), 1669-1696.

Earley, P. S., \& Ang, S. (2003). Cultural intelligence: individual interactions across cultures. Palo Alto, CA: Stanford University Press.

Gritsenko, V. V., Pavlova, O. S., Tkachenko, N. V., Usubian, Sh. A., Khukhlaev, O. E., \& Shorohova, V. A. (2020). Analysis of foreign empirical models of intercultural competence and methods for its evaluation. Sovremennaya Zarubezhnaya Psihologiya [Journal of Modern Foreign Psychology], 1(9), 103-113. doi:10.17759/jmfp.2020090111 (in Russian)

Gutentag, T., Horenczyk, G., \& Tatar, M. (2018). Teachers' approaches toward cultural diversity predict diversity-related burnout and self-efficacy. Journal of Teacher Education, 69(4), 408-419.

Hu, L., \& Bentler, P. M. (1999). Cutoff criteria for fit indexes in covariance structure analysis: Conventional criteria versus new alternatives. Structural Equation Modeling: A Multidisciplinary Journal, 6(1), 1-55. doi:10.1080/10705519909540118

Khukhlaev, O. E., \& Chibisova, M. Yu. (2010). Theoretical and practical issues of intercultural communication: contemporary trends. Psikhologicheskaya Nauka i Obrazovanie psyedu.ru [Psychological Science and Education psyedu.ru], 2(5). Retrieved from http://psyjournals.ru/psyedu_ru/2010/n5/Huhlaev_Chibisova.shtml (in Russian)

Khukhlaev, O. E., Gritsenko, V. V., Pavlova, O. S., Tkachenko, N. V., Usubyan, Sh. A., \& Shorohova, V. A. (2020). Comprehensive model of intercultural competence: theoretical substantiation. RUDN Journal of Psychology and Pedagogics, 1(17), 13-28. doi:10.22363/2313-1683-2020-17-1-13-28

Larin, N. A. (2017). Fenomen emocional'nogo vygoraniya pri mezhkul'turnom vzaimodejstvi [The phenomenon of emotional burnout during intercultural interacti]. Psihologiya i Psihotekhnika, 3, 1-9. Retrieved from https://nbpublish.com/library_read_article.php?id=23962 (in Russian)

Lebedeva, N. M. (2009). Teoreticheskie podhody $\mathrm{k}$ issledovaniyu vzaimnyh ustanovok i strategij mezhkul'turnogo vzaimodejstviya migrantov i naseleniya Rossii [Theoretical approaches to the study of mutual attitudes and strategies for intercultural interaction of migrants and the population of Russia]. In N. M. Lebedeva \& A. N. Tatarko (Eds.), Strategii mezhkul'turnogo vzaimodeistviya migrantov $i$ naseleniya Rossii [Strategies for intercultural interaction between migrants and the population of Russia] (pp. 10-62). Moscow: RUDN University. (in Russian) 
Lebedeva, N. M., \& Tatarko, A. N. (Eds.). (2009). Strategii mezhkul'turnogo vzaimodeistviya migrantov inaseleniya Rossii [Strategies for intercultural interaction between migrants and the population of Russia]. Moscow: RUDN University. (in Russian)

Leung, K., Ang, S., \& Tan, M. L. (2014). Intercultural competence. The Annual Review of Organizational Psychology and Organizational Behavior, 1, 489-519.

Lichutina, E. I. (2017). Situational judgments test. Ekonomika i menedzhment innovatsionnykh tekhnologii [Economics and Innovations Management], 1. Retrieved from http://ekonomika.snauka.ru/en/2017/01/13784 (in Russian)

Marsh, H. W., Balla, J. R., \& McDonald, R. P. (1988). Goodness of fit indexes in confirmatory factor analysis: The effect of sample size. Psychological Bulletin, 103, 391-410.

Maslach, C., Schaufeli, W. B., \& Leiter, M. P. (2001). Job burnout. Annual Review of Psychology, 52, 397-422. doi:10.1146/annurev.psych.52.1.397

Matsumoto, D., \& Hwang, H.C. (2013). Assessing cross-cultural competence: a review of available tests. Journal of Cross-Cultural Psychology, 44, 849-873.

Matsumoto, D., Leroux, J., Ratzlaff, C., Tatani, H., Uchida, H., Kim, C. \& Arak, S. (2001). Development and validation of a measure of intercultural adjustment potential in Japanese sojourners: The Intercultural Adjustment Potential Scale (ICAPS). International Journal of Intercultural Relations. 25, 483-510.

MIRIPS (Mutual Intercultural Relations in Plural Societies). (n.d.). Retrieved from http://www.victoria.ac.nz/cacr/research/mirips

Schnabel, D., Kelava, A., Van de Vijver, F., \& Seifert, L. (2015). Examining psychometric properties, measurement invariance, and construct validity of a short version of the Test to Measure Intercultural Competence (TMIC-S) in Germany and Brazil. International Journal of Intercultural Relations, 49, 137-155.

Shadrikov, V. D. (2010). The problems of psychological theory of abilities. Psychology. Journal of the Higher School of Economics, 3(7), 41-56. (in Russian)

Soldatova, G. U., Chigarkova, S. V., \& Rasskazova, E. I. (2018). Approbation of Expanded Cultural Intelligence Scale in Russian. Psychology. Journal of the Higher School of Economic, 3(15), 510526. (in Russian)

Tatar, M., Ben-Uri, I., \& Horenczyk, G. (2011). Assimilation attitudes predict lower immigrationrelated self-efficacy among Israeli immigrant teachers. European Journal of Psychology of Education, 26, 247-255.

Tatar, M., \& Horenczyk, G. (2003). Diversity-related burnoutamong teachers. Teaching and Teacher Education, 19, 397-408.

Van der Zee, K., \& Brinkmann, U. (2004). Construct validity evidence for the intercultural readiness check against the Multicultural Personality Questionnaire. International Journal of Selection and Assessment, 12(3), 285-290.

Van Der Zee, K. I., \& Van Oudenhoven, J. P. (2000). The Multicultural Personality Questionnaire: A multidimensional instrument of multicultural effectiveness. European Journal of Personality, 14(4), 291-309.

Van der Zee, K. I., \& Van Oudenhoven, J. P. (2001). The Multicultural Personality Questionnaire: Reliability and validity of self- and other ratings of multicultural effectiveness. Journal of Research in Personality, 35, 278-288.

Whaley, A. L, \& Davis, K. E. (2007). Cultural competence and evidence-based practice in mental health services: a complementary perspective. American Psychologist, 62, 563-574. 
Oleg E. Khukhlaev - Head of the department, Department of Cross-cultural Psychology and Multicultural Education, Moscow State University of Psychology \& Education, PhD in Psychology.

Research Area: cross-cultural psychology, intergroup relations, social-psychological training.

E-mail: huhlaevoe@mgppu.ru

Valentina V. Gritsenko - Professor, Department of Cross-cultural Psychology and Multicultural Education, Moscow State University of Psychology \& Education, DSc in Social Psychology.

Research Area: cross-cultural psychology, psychology of migration, socio-psychological adaptation.

E-mail: gritsenko2006@yandex.ru

Anna V. Makarchuk - Program Director, Federal research and methodology center for tolerance psychology and education, $\mathrm{PhD}$ in Psychology.

Research Area: intercultural training, psychology of the intercultural communication, tolerance psychology and education.

E-mail: anna.m@tolerancecenter.ru

Olga S. Pavlova - Associate Professor, Department of Cross-cultural Psychology and Multicultural Education, Moscow State University of Psychology \& Education, PhD in Psychology.

Research Area: cross-cultural psychology, psychology of religion, cross-cultural technology of psychological assistance.

E-mail: os_pavlova@mail.ru

Natalia V. Tkachenko - Associate Professor, Department of Cross-cultural Psychology and Multicultural Education, Moscow State University of Psychology \& Education, PhD in Psychology.

Research Area: cross-cultural psychology, intergroup relations, multicultural education, psychological assistance of young researchers, field ethnopsychology.

E-mail: tkachenkonv@mgppu.ru

Shushanik A. Usubian - PhD student, Department of Cross-cultural Psychology and Multicultural Education, Moscow State University of Psychology \& Education.

Research Area: cross-cultural psychology, psychology of intergroup relations, study abroad.

Contacts: usubyansha@mgppu.ru

Valeria A. Shorokhova - Senior Lecturer, Department of Cross-cultural Psychology and Multicultural Education, Moscow State University of Psychology \& Education.

Research Area: cross-cultural psychology, psychology of religion.

E-mail: shorohovava@mgppu.ru 